Egyptian Journal of Archaeological and Restoration Studies
An international peer-reviewed journal published bi-annually
www.ejars.sohag-univ.edu.eg

Original article

\title{
CHARACTERIZATION AND CONSERVATION STUDY OF ANCIENT EGYPTIAN BRONZE BELLS
}

\author{
Abdelbar, M. \\ Conservation dept., Faculty of Archaeology, Damietta Univ., Damietta, Egypt. \\ E-mail address:ma00@du.edu.eg
}

\begin{tabular}{|c|c|}
\hline Article info. & EJARS - Vol. 11 (2) - Dec. 2021: 165-174 \\
\hline Article history: & Abstract: \\
\hline Received: $12-10-2020$ & Two Bronze Bells were excavated through the Egyptian-Italian \\
\hline Accepted: 5-10-2021 & expedition in Medinet Madi, Fayoum, Egypt. They are dated back \\
\hline Doi: $10.21608 /$ ejars.2021.210367 & $\begin{array}{l}\text { to the Late Period (664-332 BC) preserved in the store museum } \\
\text { of Kom Oshim, Fayoum governorate. They were manufactured by } \\
\text { the lost wax process. Visual examination, USB digital microscope, } \\
\text { metallographic examination, scanning electron microscope with } \\
\text { energy dispersive spectroscopy, portable X-ray fluorescence and } \\
X \text {-ray diffraction were used in this study to elucidate the micro- } \\
\text { structure and elemental chemical composition of the bells, and } \\
\text { identify the corrosion morphology. The results indicated that the bells }\end{array}$ \\
\hline Keywords: & $\begin{array}{l}\text { had been manufactured with a ternary alloy } \mathrm{Cu}-\mathrm{Sn}-\mathrm{Pb} \text {. Two-phased } \\
\text { microstructure the } \alpha-\mathrm{Cu} \text { phase and the }(\alpha-\mathrm{Cu}+\delta-\mathrm{Sn}) \text { eutectoid }\end{array}$ \\
\hline Dell & could be observed with Pb small globules and scattered porosity. \\
\hline IIn bronze & The corrosion products were identified as atacamite, paratacamite \\
\hline Analysis & and malachite for the bronze bell, and goethite for the iron clapper. \\
\hline Corrosion & Conservation treatments included cleaning and protection processes \\
\hline Treatments & $\begin{array}{l}\text { to reveal the bells shape and provide better protection agalnst } \\
\text { corrosion. }\end{array}$ \\
\hline
\end{tabular}

\section{Introduction}

Bells have been made for about 4000 years. They were usually used in Assyria, Persia, Babylon, China, Greece and Egypt [1-3]. In ancient Egypt, bells were known since the pre-dynastic (before $3100 \mathrm{BC}$ ) until the Coptic period (395-642 CE); they have a religious and functional significance. Bells were used not only as a musical instrument but also as a pendant hanging around the neck of the animals of the household and as sacrificial animals like dogs and cows [4-7]. Bronze bells are the most common type of bell but were also occasionally made of gold or silver by emphasized their appearance as small ornaments on Egyptian necklaces [4,5]. Bronzes with varying tin content were produced for different purposes - tools, chandeliers, statues, coins, and later canons and bells. In ancient times, daily used objects such as bells were manufactured from high-tin bronze $[8,9]$. They are usually compounded of copper and tin, in the proportions of three of copper to one of tin [2]. The addition of Sn leads to further strengthening, preventing deformation of the bell by the clapper which could, in turn, alter the tone. Though, a moderate use of $\mathrm{Sn}$ is recommended to avoid fracture tendency during striking. Concerning sound, increasing the tin content leads to an increase in the duration of the sound. However, other elements such as lead, that was commonly 
found in copper alloys, can be used to increase the fluidity of the molten metal, and thus facilitated casting without detracting from the strength of the alloy. In bell manufacturing, lead would lead to a decrease in the sound duration [10-13]. Traditionally, bell materials consisted of a wide variety of additional alloying elements such as $\mathrm{Zn}, \mathrm{Bi}, \mathrm{Ag}, \mathrm{Sb}, \mathrm{As}, \mathrm{Ni}, \mathrm{Fe}$, $\mathrm{P}, \mathrm{S}$ and Si. Some of these elements (e.g. $\mathrm{Zn}, \mathrm{Ni}, \mathrm{Fe}, \mathrm{Ag}, \mathrm{Sb}$ ) were introduced on purposes, while others such as sulfur and phosphorus were contaminations introduced accidentally during the bronze melting process, mainly from charcoal and coke [14, 15]. These elements will influence the final quality of bell materials and their effects on the mechanical properties including failure and fracture of tin bronzes [8]. Bells came throughout the ancient world in different shapes with various forms of handles and clappers. The spherical, conical, and various domed forms are some of the bronze bells. An internal clapper, an external hammer, or an interior pellet or pea (for spherical cloves) might give the sound. A bell is more musical than a rattle, even if the two are connected [3, 16,17]. Most ancient Egyptian bronze bells were cast using the lost-wax process, the usual technique for ancient bronze bells and most bronze objects in general [3]. We have a large number of ancient Egyptian bell molds (now in the Cairo museum, cat. \#32315 a, b) provides good evidence of metal foundry in ancient Egypt [4]. The quality of bronze casting is closely dependent on the individual steps in the technological process. Sand casting is the widely practiced technique in bells manufacturing, involves five key operations: pattern-making, core-making, molding, melting and pouring $[1,2]$. The present paper aims to make a characterization and conservation study of two bronze bells by using various laboratory methods to determine metallic composition, microstructure, and corrosion layers; providing useful information for the decision making to select appropriate treatment methods of the bell.

\section{Materials and Methods}

\subsection{Description}

The two bells under study were preserved in the store museum of Kom Oshim, Fayoum governorate, with No. (89). They were used in daily life purposes, as they were hung around the animals' neck like cows and sheep to give a sound of movement. Such practical uses make it more of a noisemaker than a musical instrument. The first bell, fig. (1-a) measures $8.5 \mathrm{~cm}$ length, the base is $5.7 \times 3.4 \mathrm{~cm}$, and weighs $102.59 \mathrm{~g}$. The second bell, fig. (1-b) measures 7.5 length, the base is $4.5 \times 3.7 \mathrm{~cm}$, and weighs $82.59 \mathrm{~g}$. The wall thickness is approx. $2 \mathrm{~mm}$. There are no decorations on the surface. The two bells have the same shape, an open base and cone-shaped without feet, and a loop handle. It is clear from figure (1-a) that there is a deformation in shape (especially in the mouth) in the large bell, which may result from soil pressures in the burial environment. The loop handle, which is the most common handle type, is usually cast in one piece with the bell's body. The big bell has an iron clapper (responsible for making the tone) strung from the interior through a piece of metal hooked throughout a perforation $[18,19]$ as shown in figure (1-a), but it is missed in the small bell as shown in figure (1-b).

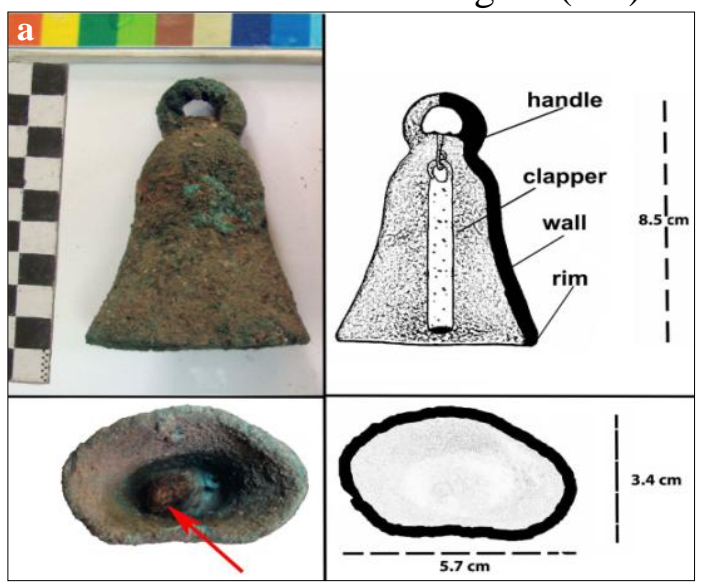




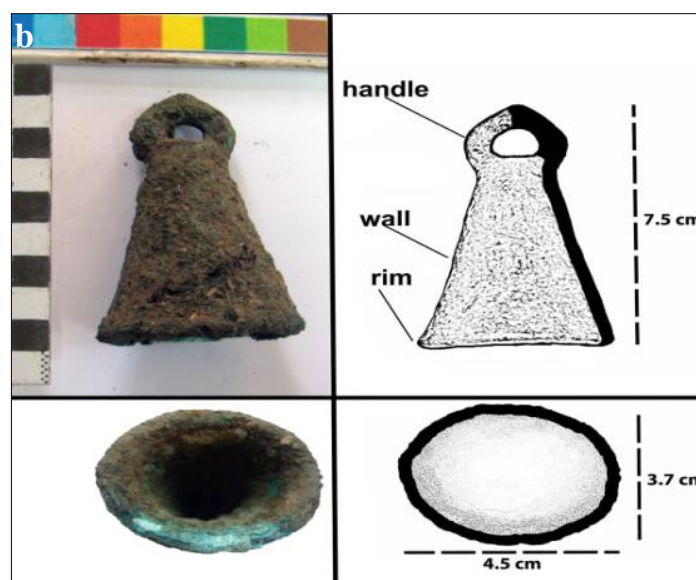

Figure (1) Shows a. left: the big bell covered with a thick corrosion crust from interior and exterior, arrow refers to the iron clapper which looks extremely corroded, right: schematic description shows the bell' main parts that consist of a handle, body, rim (base) and clapper, $\underline{\mathbf{b}}$. left: the small bell covered with a thick corrosion crust from interior and exterior, right: Schematic description shows the bell' main parts that consist of a handle, body, and rim (base), but the iron clapper is missed.

\subsection{Examination and analysis}

On-site observations and examinations were carried by using USB digital microscope to identify deterioration conditions. Elemental analysis of the bell manufacturing alloy was undertaken in situ by portable X-ray fluorescence (pXRF) using Bruker S1 TITAN and TRACER 5i Handheld XRF Spectrometer. Analysis has been directly carried out on six different spots on the bell's corroded surface without taking sample. A small, detached sample from the bell base was used for the examination by metallographic and scanning electron microscope. It was prepared as a cross-section to study the metallic microstructure by Leco L31 metallographic microscope. The crosssection was prepared by embedding the sample in epoxy resin and polished using 600, 800, 1200 and 2000 grit emery papers, and polished with $0.5 \mu \mathrm{m}$ Alumina suspension. The metallographic sample was observed before and after etching. The etching was made using an alcoholic ferric chloride solution $(240 \mathrm{ml}$ ethanol, $60 \mathrm{ml}$ hydrochloric acid and $20 \mathrm{~g}$ ferric chloride) for 5 sec. SEM observations were made through the Inspect S50 SEM (FEI company). The same pre-prepared sample for metalographic examination and another one from the iron clapper were examined under SEM/ EDS. X-ray diffraction (XRD) was undertaken with D8 advance X-ray diffractometer X. (Bruker, Germany). Two samples were analyzed by XRD to identify the composition of crystalline corrosion products of the bronze bell and the iron clapper. Conservation treatments were accomplished to remove soil deposits and corrosion products before protective coatings can be applied to the bells. Such deposits can be removed either by chemical or mechanical techniques. Protection system must be applied to passivate the bells and protect it from further corrosion.

\section{Results}

\subsection{Microscopic observations}

USB microscopic investigations of the two bells are given in fig. (2-a, b, c). They were completely covered with a thick crust of green corrosion products incorporated with soil inclusions. The iron clapper is extremely corroded and stuck firmly to the bell wall. After simple cleaning, a very small perforation was detected in the small bell's shoulders, as shown in fig. (2-c). It may be attributed to localized corrosion in soil or a result of casting defects.

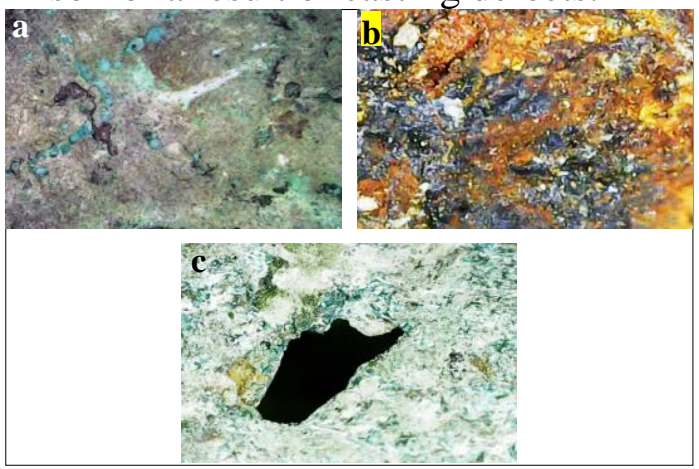

Figure (2) Shows optical microscopic images of the corroded bell surface; $\underline{\text { a. }}$ thick corrosion products mixed with soil deposits, b. oxide and hydroxide corrosion products of the iron clapper, $\underline{\mathbf{c}}$. very small perforation was observed in the small bell's shoulders. 


\subsection{Microstructure of the bell}

Metallographic and SEM/EDS investigations of the bell microstructure are shown in fig. (3-a, b, c) respectively. Energy dispersive spectroscopy (EDS) elemental mapping images showing the distribution of $\mathrm{Cu}, \mathrm{Sn}$ and $\mathrm{Pb}$ concentration in the tin-bronze alloy are given in fig. (4-a, b, c, d).

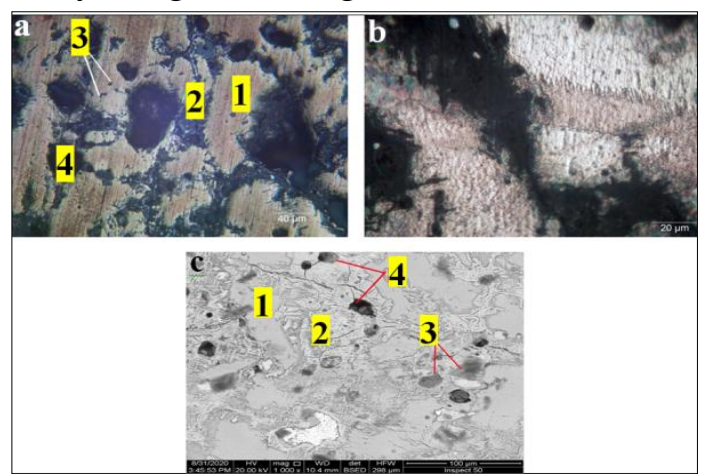

Figure (3) Shows metallographic image of polished but un-etched sample; a. 1) $\alpha-\mathrm{Cu}$ phase, 2) $\alpha-\mathrm{Cu}^{+} \delta$-Sn phase (eutectoid), 3) $\mathrm{Pb}$ globules (light dark), 4) Porosity (dark), b. metallographic image of polished and etched sample at a higher magnification, c. SEM image confirm the same above microsturcture
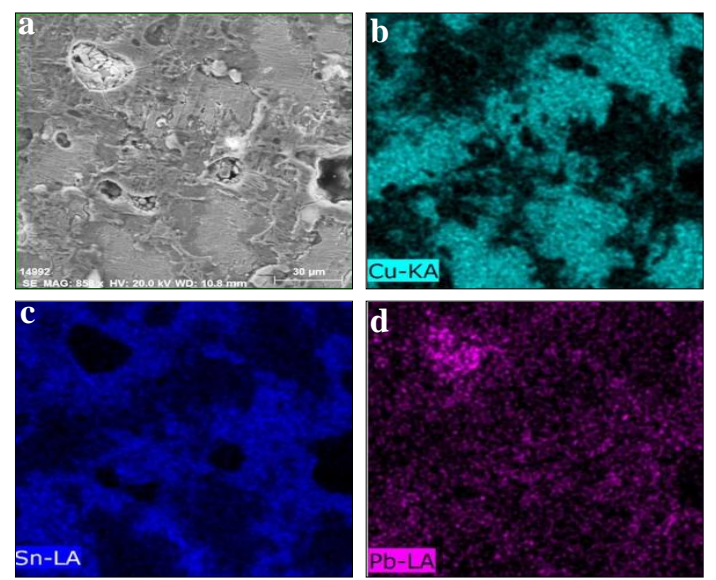

Figure (4) Shows EDS elemental mapping images of the distribution of chemical elements in the alloy metallic core

\subsection{Chemical compositions}

Elemental analysis by $p$ XRF on the corroded surface will recognize the metallic elements attributed to the bulk alloy, corrosion products and soil deposits, tab. (1-a). It is clear that the main alloying elements of bell material were $\mathrm{Cu}, \mathrm{Sn}$ and $\mathrm{Pb}$. The $\mathrm{Cu}$ content varies from 66.81 wt. \% to 81.53 wt. \%, the Sn content varies from 5.49 wt. $\%$ to 13.66 wt. $\%$ and the $\mathrm{Pb}$ content varies from $1.36 \mathrm{wt}$. $\%$ to $3.76 \mathrm{wt}$. \%. The high silicon and calcium content vary from 2.67 wt. $\%$ to 5.30 wt. \% and from 2.18 to 4.19 wt. \% respectively. EDS analysis results of the metallic core are given in fig. (5) and tab. (1-b). It can be noted that the bell main elements are copper, tin and lead, where $\mathrm{Cu}$ is 61.71 wt. \%, $\mathrm{Sn}$ is 29.31 wt. \% and $\mathrm{Pb}$ is 8.98 wt. \%. Iron and nickel are found as impurities. EDS analysis of the iron clapper are presented in fig. (6) and tab. (1-c). The iron content varies from 48.48 to 92.98 wt. \%.

Table (1-a) $p$ XRF results of different spots on the two bell's corroded surface (wt \%).

\begin{tabular}{ccccccc}
\hline $\begin{array}{c}\text { Spot } \\
(\text { Element } \boldsymbol{w} \text { \%) }\end{array}$ & $\mathbf{1}$ & $\mathbf{2}$ & $\mathbf{3}$ & $\mathbf{4}$ & $\mathbf{5}$ & $\mathbf{6}$ \\
\hline $\mathbf{M g}$ & 0.568 & 0.089 & 0.295 & 0.971 & 0.117 & 0.420 \\
$\mathbf{A l}$ & 0.414 & 0.809 & 0.677 & 0.332 & 0.789 & 0.179 \\
$\mathbf{S i}$ & 5.302 & 4.453 & 4.360 & 2.672 & 3.311 & 3.110 \\
$\mathbf{P}$ & 0.191 & 0.122 & 0.173 & -- & 0.044 & 0.140 \\
$\mathbf{S}$ & 0.432 & 0.364 & 0.143 & --- & -- & 0.883 \\
$\mathbf{C l}$ & 5.531 & 7.429 & 6.652 & 3.990 & 3.072 & 8.452 \\
$\mathbf{K}$ & 0.699 & 0.644 & 0.606 & 0.178 & 0.338 & 0.497 \\
$\mathbf{C a}$ & 3.071 & 2.178 & 3.170 & 2.449 & 4.190 & 2.814 \\
$\mathbf{F e}$ & 0.638 & 0.592 & 0.698 & 0.187 & 0.430 & 0.474 \\
$\mathbf{N i}$ & 0.252 & 0.126 & 0.265 & 0.209 & 0.117 & 0.416 \\
$\mathbf{C u}$ & 66.813 & 69.704 & 68.492 & 81.526 & 70.158 & 72.064 \\
$\mathbf{S n}$ & 13.344 & 11.497 & 13.111 & 5.487 & 13.658 & 9.076 \\
$\mathbf{P b}$ & 2.743 & 1.981 & 1.356 & 1.987 & 3.764 & 1.473 \\
\hline
\end{tabular}
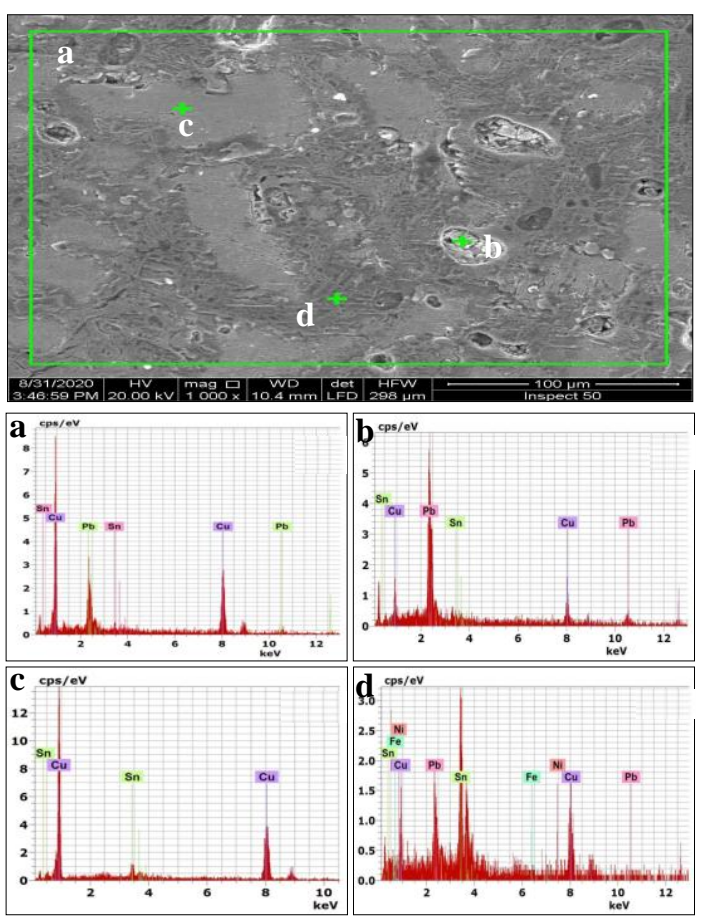

Figure (5) Shows SEM image the corresponding EDS analysis of some phases in the bell's metallic core. 
Table (1-b) EDS analysis results of the chemical composition of the bell.

\begin{tabular}{cccccc}
\hline $\begin{array}{c}\text { Spot } \\
\text { (Element wt \%) }\end{array}$ & $\mathrm{Fe}$ & $\mathrm{Ni}$ & $\mathrm{Cu}$ & $\mathrm{Sn}$ & $\mathrm{Pb}$ \\
\hline $\mathrm{A}$ & --- & --- & 61.71 & 29.31 & 8.98 \\
$\mathrm{~B}$ & --- & -- & 23.08 & 6.75 & 70.17 \\
$\mathrm{C}$ & --- & --- & 87.75 & 12.25 & --- \\
$\mathrm{D}$ & 0.89 & 0.22 & 40.29 & 46.72 & 11.88 \\
\hline
\end{tabular}

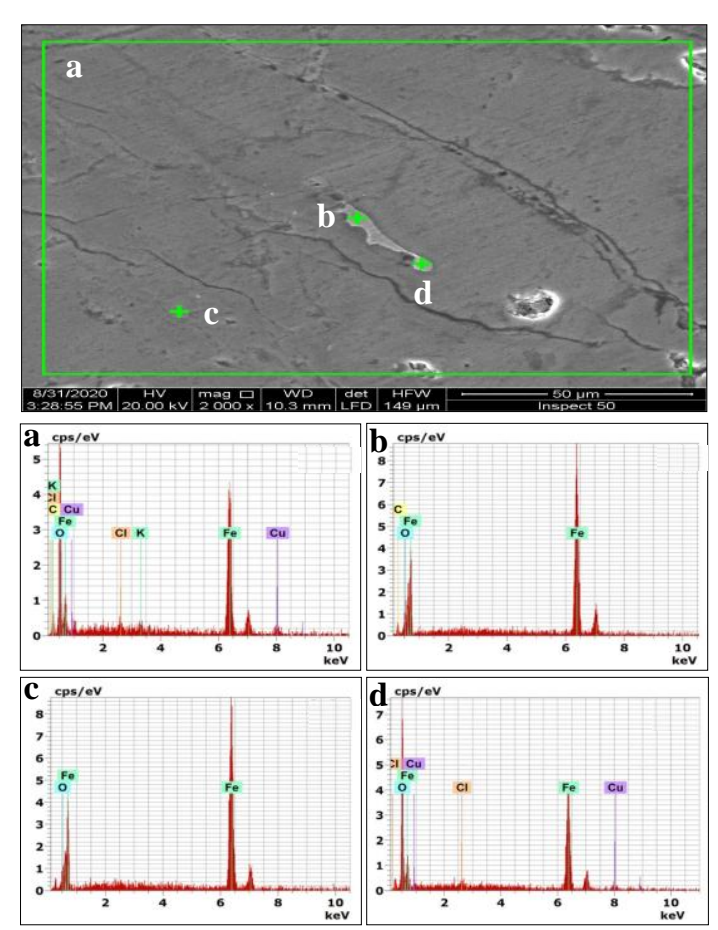

Figure (6) Shows SEM image the corresponding EDS analysis of different spots in the iron clapper.

Table (1-c) EDS analysis results of different spots in the iron clapper.

\begin{tabular}{ccccccc}
\hline $\begin{array}{c}\text { Spot } \\
\text { (Element wt \%) }\end{array}$ & $\mathrm{C}$ & $\mathrm{O}$ & $\mathrm{Cl}$ & $\mathrm{K}$ & $\mathrm{Fe}$ & $\mathrm{Cu}$ \\
\hline $\mathrm{A}$ & 10.60 & 36.00 & 0.70 & 0.64 & 48.48 & 3.58 \\
$\mathrm{~B}$ & 10.55 & 7.52 & --- & --- & 81.94 & -- \\
$\mathrm{C}$ & -- & 7.02 & -- & -- & 92.98 & -- \\
$\mathrm{D}$ & --- & 42.03 & 0.87 & -- & 54.41 & 2.69 \\
\hline
\end{tabular}

\subsection{Characterization of corrosion pr- oducts}

XRD patterns of corrosion products formed on the two-bell surface and the iron clapper, fig. (7-a, b) and the results presented in tab. (2) revealed that the green corrosion products were atacamite, paratacamite $\left(\mathrm{CuCl}_{2}\right.$. $\left.3 \mathrm{Cu}(\mathrm{OH})_{2}\right)$ and malachite $\left(\mathrm{Cu}_{2} \mathrm{CO}_{3}(\mathrm{OH})_{2}\right)$ incorporated with gypsum $\left(\mathrm{CaSO}_{4} \cdot 2 \mathrm{H}_{2} \mathrm{O}\right)$. Whereas the corrosion products of the iron clapper were goethite $(\mathrm{FeO}(\mathrm{OH}))$ contains quartz $\left(\mathrm{SiO}_{2}\right)$ particles.
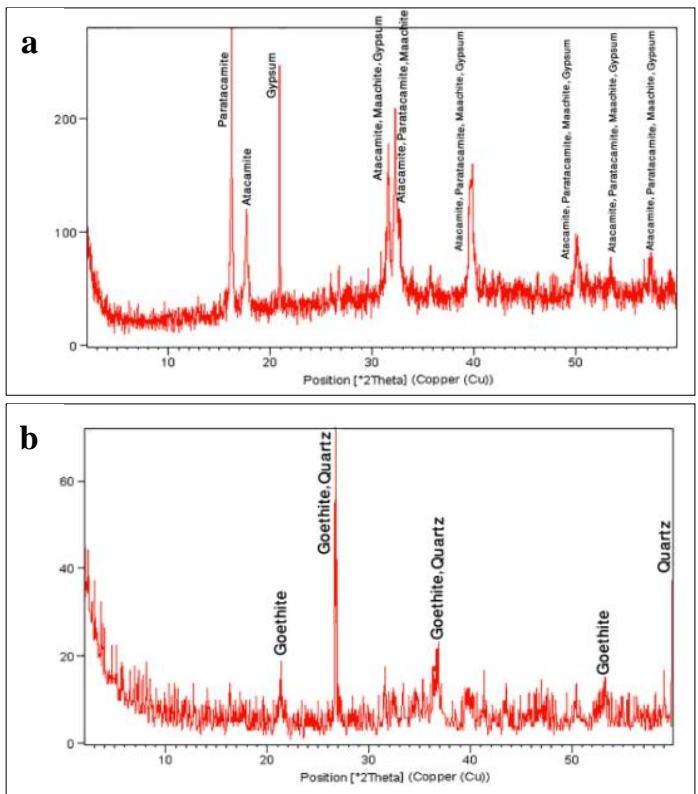

Figure (7) Shows XRD patterns of corrosion pro-

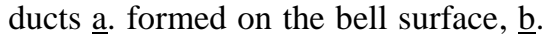
sampled from the iron clapper.

Table (2) XRD analytical results of corrosion products from the bronze bell and iron clapper.

\begin{tabular}{ccccc}
\hline Sample & Mineral Name & Chemical Formula & Intensity & Ref. Code \\
\hline Bell & Atacamite & $\mathrm{CuCl}_{2} .3 \mathrm{Cu}(\mathrm{OH})_{2}$ & Major & $02-0146$ \\
surface & Paratacamite & $\mathrm{CuCl}_{2} 3 \mathrm{Cu}(\mathrm{OH})_{2}$ & Major & $19-0389$ \\
& Malachite & $\mathrm{Cu}_{2} \mathrm{CO}_{3}(\mathrm{OH})_{2}$ & Minor & $10-0399$ \\
& Gypsum & $\mathrm{CaSO}_{4} .2 \mathrm{H}_{2} \mathrm{O}$ & Traces & $00-01807$ \\
Iron & Goethite & $\mathrm{FeO}(\mathrm{OH})$ & Major & $01-081-0463$ \\
clapper & Quartz & $\mathrm{SiO}_{2}$ & Traces & $00-005-0490$ \\
\hline
\end{tabular}

\section{Discussion}

From metallographic investigations, it is observed that the alloy represents the tin bronze alloy. It consisted basically of a mixture of the $\alpha-\mathrm{Cu}$ phase and the $(\alpha-\mathrm{Cu}+$ $\delta$-Sn) eutectoid, in proportions depending on tin content and mold materials during casting. These latter affect the cooling rate, which in turn, influences the grain size and the nature of the $\alpha$ phase as well as the amount of the $(\alpha+\delta)$ inter-dendritic eutectoid $[14,20]$. When lead is added to low-tin bronzes, typically castings, the lead does not alloy with the copper or tin and occurs as small globules throughout the structure $[20,21]$. It can be noted from EDS elemental 
mapping that the distribution of copper $(\mathrm{Cu})$ and tin $(\mathrm{Sn})$ indicate homogeneous matrix microstructure. According to XRF and EDS results, it can be concluded that the bell-making alloy was tin-bronze alloy. Bells were often made in antiquity of ternary tin bronzes consisting of about 20-25 wt \% tin, $2-10$ wt $\%$ lead, the remainder being copper, which considered the most important alloy for bell manufacture [13,20], Gadalla [4] was also confirmed that the chemical analysis of the typical ancient Egyptian bell was found to be $82.4 \mathrm{wt} \%$ copper, 16.4 wt $\%$ tin, and $1.2 \mathrm{wt} \%$ lead. Silicon and calcium which have detected by $\mathrm{pXRF}$ may be related to soil inclusions which incorporated with the corrosion products. The chloride content (3.072 wt \% to 8.452 wt \%) can be also attributed to the presence of soluble salts in burial environment. Based on the EDS results of the iron clapper, the high oxygen content (up to $42.03 \mathrm{wt} \%$ ) could be attributed to iron corrosion products (typically iron (III) hydroxides). The $\mathrm{Cu}$ content may be referring to copper corrosion products, whereas the clapper is in direct contact with the bell body. It can be clear that the high carbon content showed in spectrum $\mathrm{E}$ and $\mathrm{F}$ (up to $10.60 \mathrm{wt} \%$ ) could be attributed to epoxy resin which has been used for preparing the crosssection, not for the iron alloy. Because iron is seldom pure and minor levels of other components can introduce very different properties into the resultant alloy. The alloying element of greatest interest is carbon, which in concentrations ranging from 0 to 5 per cent greatly affects the properties of the different alloys formed [22]; wrought iron contains little carbon (not over $0.35 \mathrm{wt} \%$ ); steel has a moderate carbon content (0.1-1.9 wt \%); and cast iron has a high carbon content (2-4 wt \%) [20]. Ancient iron can derive from fortuitous examples of meteoric iron, from native iron (telluric iron), or from smelted iron ores. Meteoric iron has provided early Egypt with no reliable and continuous supply source [12]. This usually contains Ni content approximately $10 \mathrm{wt} \%$ and is thus much harder and more difficult to work. The nickel content varies between $4 \mathrm{wt} \%$ and $26 \mathrm{wt}$ $\%$ and can be easily detected, while there appear to be no ores that can homogenize nickel by direct melting [23]. Although Egypt has some remarkable iron ore deposits, but there is no evidence that these deposits were ever worked before the late or Graeco-Roman periods. The earliest shreds of iron smelting evidence in Egypt dated to about 580 B.C., where a large quantity of iron slag and some ore were found in the delta region at Naucratis and Defenna [24]. The results of XRD analysis showed that the two bells were subjected to being buried in wet soil rich in chloride ions and oxygen that were covered with a thick crust of green corrosion products incorporated with soil deposits. Quartz $\mathrm{SiO}_{2}$ and gypsum $\mathrm{CaSO}_{4} \cdot 2 \mathrm{H}_{2} \mathrm{O}$ could be attributed to soil encrustations, while basic copper chloride compounds indicate the increasing content of chloride in soils which accelerates the corrosion rate through the destruction of the passive layer. Many researchers have studied corrosion processes of archaeological bronze objects in soil environment [25-30]. Those variable studies have led to that the most important parameters which have a severe degree of deterioration in the soil are soil $\mathrm{pH}$, moisture content, temperature, acidification, salt content, and metallurgical characteristics of the metallic objects such as microstructure and composition. The bells are corroded in soil by forming a smooth noble patina (cuprite $\mathrm{Cu}_{2} \mathrm{O}$ ) on the surface that may become malachite due to the reaction between copper oxides and carbonate/bicarbonate dissolved in soil water. In addition, presence of chlorine ions in the burial environment penetrates the cuprite layer, forming 
a crystalline white layer of cuprous chloride (nantokite $\mathrm{CuCl}$ ). This layer remains stable in the absence of both oxygen and moisture. During burial or after excavation, the artifacts are exposed to moisture and oxygen, cuprous oxide (cuprite) is produced by hydrolysis of cuprous chloride, and the hydrochloric acid will also be arisen by this reaction producing more cuprous chloride which promotes corrosion of the remaining metal. Cuprous chloride activity is increased when it is in contact with copper and a drop of water. It turns into a pale green layer in the phase of base copper chloride $\left(\mathrm{CuCl}_{2} \cdot 3 \mathrm{Cu}(\mathrm{OH})_{2}\right)$ paratacamite, then turns to atacamite, which damage the object and may change its shape [31-35]. Regarding the corrosion process of the iron clapper, it could be attributed to the galvanic corrosion which arises between the two metals (iron clapper and bell metal) differs in electrochemical potential in the presence of electrolytic solution. The less resistant metal (iron) becomes anodic and the more resistant metal (copper) becomes cathodic. Usually, the cathodic metal corrodes very little or not at all, while the anodic metal is highly corroded $[36,37]$. When iron corrodes during burial underground, an outer layer is found on its surface composed of a mixture of iron corrosion products (iron (III) hydroxide oxides). The second layer contains iron corrosion products in a lower oxidation state, usually magnetite. Goethite and magnetite are two common iron oxides that form during burial, with the latter forming when the level of dissolved oxygen is low. Heavily chloride-ions in soils can be guaranteed to create severe pitting or delamination of iron, often with severe loss, with or complete conversion to iron corrosion products $[35,38,39]$.

\section{Treatment Conservation}

Depending on the examination and analysis results, conservation procedures were taken to remove the superficial encrustations/ deposits from the bell surface and preserve it against further attack. Compared with chemical cleaning process, the corrosionmechanical cleaning is the most convenient and does not introduce chemicals into the artifact, which may compromise the shape of an object [22,34]. In the present case, the thick corrosion layers are like a support to the bell thin wall from both sides. The complete removal of these layers using chemical solutions will weaken the bell's structure or cause a significant loss of shape. In this case, the use of mechanical cleaning within brushes, scalpels and dental drilling machine is the preferred option to reduce the thickness of the hardthick corrosion layers in a controlled way to reach a smooth layer that reveal the shape and modify the surface appearance. Active corrosion spots (the light green powdery eruption) were also mechanically cleaned by pointed needle under the magnifying glass [40]. The final treatment stage is to protect the bells against further corrosion; this can be achieved by treating the bells with corrosion inhibitor Benzotriazole 3 wt \% in alcohol to stabilize the active corrosion areas. Then, a clear protective coating of Permalac (N-Butyl acetate) was applied by soft brush. This coat is developed in 1995 that is an air-drying lacquer in less than 5 minutes manufactured by Peacock Laboratories. It can be easily and completely removed by wiping the surface down with acetone [41-43], fig. (8). To slow down the process of deterioration, the two bells were housed in a microclimate polyethylene storage box with silica gel to control relative humidity. Silica gel should be checked and reconditioned regularly to be dry. The length of time silica gel will keep the desired RH before it needs to be changed, will depend on the box air exchange rate, the external humidity, and the quantity of gel $[40,44,45]$. 


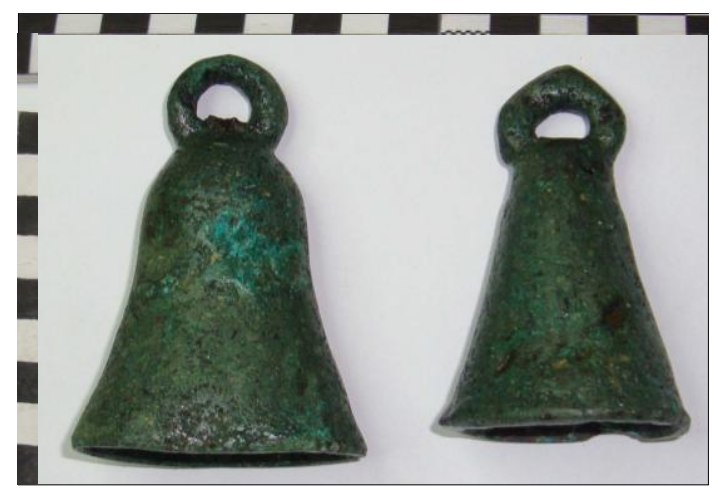

Figure (8) Shows the two bells after the treatment processes.

\section{Conclusion}

High tin-bronze alloy is the preferred alloy for bells making which is containing about 22-24 wt \% of tin, because it has given a pleasing sound quality when struck. Through metallurgical analysis of the bell manufacturing alloy, two-phased microstructure, the $\alpha$-Cu phase and the $(\alpha-\mathrm{Cu}+\delta$-Sn) eutectoid was observed with $\mathrm{Pb}$ small globules and scattered porosity. The iron clapper is completely transformed into corrosion products; therefore, it was difficult to identify its microstructure and elemental composition. Based on the corrosion results, the degradation of the two bells is due to aggressive/corrosive conditions of the burial environment, where soluble chloride and water content are the main corrosive features. Because the bell body is sandwiched between outer and inner corrosion layers supporting the bell wall, the cleaning processes were carried out to reduce the thickness of the corrosion layers without complete removal, in order to preserve the stability and integrity of the bell structure.

\section{Acknowledgements}

The author would like to thank Mr. Mostafa Faysal, the general director of the store of Kom Oshim museum, for all assistance and support.

\section{References}

[1] Strafford, K., Newell, R., Audy, K., et al. (1996). Analysis of bell material from the Middle Ages to the recent time, Endeavour, Vol. 20 (1), pp. 2227.
[2] Gatty, A. (1848). The bell: Its origin, history, and uses, Ukorge Bell, London.

[3] Abd El-Hamid, M. (2015). Shapes and functions of the bell in Graeco-Roman Egypt, J. of Association of Arab Universities for Tourism and Hospitality, Vol. 12 (1), pp:. 85-111.

[4] Gadalla, M. (2016). The enduring ancient Egyptian musical system: Theory and practice, Tehuti Research Foundation, USA.

[5] Blades, J. (1970). Percussion instruments and their history, F.A. Praeger, NY.

[6] Pease, A. (1904). Notes on some uses of bells among the Greeks and Romans, Harvard Studies in Classical Philology, Vol. 15, pp. 29-59.

[7] Abed El Mohsen, I. (2017). Bells in the ancient near east (Iran-Iraq-Hebrews): in Arabic, J. of General Union of Arab Archaeologists, Vol. 18 (18), pp. 348379.

[8] Audy, J. \& Audy, K. (2009). Effects of microstructure and chemical composition on strength and impact toughness of tin bronzes, Modern Machinery Science J., Vo. 6 (6), pp. 124-129.

[9] Jabłońska, M., Maciąg, T., Nowak, M., et al. (2019). Thermal and structural analysis of high-tin bronze of chemical composition corresponding to the composition of the singing bowl, J. of Thermal Analysis and Calorimetry, Vol. 137, pp. 735-741.

[10] Hodges, H. (1964). Artifacts, an introduction to early materials and technology, $1^{\text {st }}$ ed., John Baker, London.

[11] Brown, D. (1976). Bronze and pewter, in: Strong, D. \& Brown, D., (eds.) Roman Crafts, Duckworth, London, pp. 25-42.

[12] Ogden, J. (2000). Metals, in: Nicholson, P. \& Shaw, I., (eds.) Ancient Egyptian materials and technology, Cambridge Univ. Press, London, pp. 148-176. 
[13] Vazdirvanidi, A. \& Pantazopoulo, G. (2017). Metallographic study of great anthony historical bronze bells of apostle Andrew Skete in Mount Athos, Greece, Metallogr. Microstruct. Anal., Vol. 6, pp. 340-351.

[14] Audy, J. \& Audy, K. (2009). Analysis of bell materials: Tin bronzes, China Foundry, Vol. 58 (1), pp. 77-81.

[15] Nadolski, M. (2017). The evaluation of mechanical properties of high-tin bronzes, Archives of Foundry Engineering, Vol. 17 (1), pp. 127-130.

[16] Johns, C. (2019). The industrial revolution-lost in antiquity-found in the renaissance, Lulu pub., USA.

[17] Harper, P. \& Pittman, H. (2013). Essays on near eastern art and archaeology in honor of Charles Kyrle Wilkinson, Metropolitan Museum of Art, NY.

[18] Villing, A. (2002). For whom did the bell toll in ancient Greece? Archaic and classical Greek bells at Sparta and Beyond, The Annual of the British School at Athens, Vol. 97, pp. 223295.

[19] Gao, M., Cao, Y., Zeng, X., et al. (2011). Microstructure characteristics and acoustic properties of laser repaired Chinese bronze bells 2300 years ago, J. of Alloys and Compounds, Vol. 509, pp: 953-956.

[20] Scott, D.A. (1991). Metallography and microstructure of ancient and historic metals, The Getty Conservation Institute, Los Angeles.

[21] Silva, R., Figueiredo, E., Araújo, M., et al. (2008). Microstructure interpretation of copper and bronze archaeological artefacts from Portugal, Materials Science Forum, Vols. 587588, pp. 365-369.

[22] Cronyn, J. (1990). The elements of archaeological conservation, Routledge, London.
[23] Tylecote, F. (1992). A history of metallurgy, $2^{\text {nd }}$ ed., The Institute of Materials, London.

[24] Scheel, B. (1989). Egyptian metalworking and tools, Shire Egyptology, Great Britain.

[25] Gerwin, W. \& Baumhauer, R. (2000). Effect of soil parameters on the corrosion of archaeological metal finds, Geoderma, Vol. 96, pp. 63-80.

[26] Nord, A., Mattsson, E. \& Tronner, K. (2005). Factors influencing the longterm corrosion of bronze artefacts in soil, Protection of Metals, Vol. 41, (4), pp. 309- 316.

[27] Angelini, E., Rosalbino, F., Grassini, S., et al. (2007). Simulation of corrosion processes of buried archaeological bronze artifacts, in: Dillmann, P., Béranger, G., Piccardo, P., et al. (eds.) Corrosion of Metallic Heritage Artifacts, Cambridge: Woodhead Pub. Ltd, England, pp. 203-218.

[28] Sandu, I., Mircea, O., Silache, V., et al. (2012). Influence of archaeological environment factors in alteration processes of copper alloy artifacts, Microscopy Research and Technique, Vol. 75, pp. 1646-1652.

[29] Oudbashi, O. (2015). Multianalytical study of corrosion layers in some archaeological copper alloy artefacts, Surf. Interface Anal., Vol. 47, pp. 1133-1147

[30] Galai1, M., Benqlilou, H., Touhami, M., et al. (2018). Comparative analysis for the corrosion susceptibility of copper alloys in sandy soil, Environ. Eng. Res., Vol. 23 (2), pp. 164-174.

[31] Weisser, T. (1987). The use of sodium carbonate as a pre-treatment for difficultto-stabilise Bronze, in: Black, J. (ed.) Recent Advances in the Conservation and Analysis of Artifacts, Institute of Archaeological, Summer School Press, London, pp. 105-108. 
[32] Scott, D. (1990). Bronze disease: A reviews of some chemical problems and the role of relative humidity, JAIC, Vol. 29, pp. 193-206.

[33] Fischer, W., Wagner, B., Siedlarek, H., et al. (1997). The influence of chloride ions and light on the corrosion behavior of copper alloys in aqueous environment with special regard to bronze disease, in: MacLeod, I., Pennec, S. \& Robbiola L. (eds.) METAL 95: Proc. of the Int. ICOM-CC Metal WG Conf., Semur-en-Auxois, James \& James, London, pp. 89-94.

[34] Scott, D. (2002). Copper and bronze in art: Corrosion, colorants and conservation, Getty Conservation Institute, Los Angeles.

[35] Selwyn, L. (2004). Metals and corrosion: A handbook for conservation professional, Canadian Conservation Institute, Ottawa, Canada.

[36] Fontana, M. (1987). Corrosion engineering, $3^{\text {rd }}$ edition, McGraw-Hill, Inc., NY.

[37] Shreir, L., Jarman, R. \& Burstein, G. (1994) Principles of corrosion and oxidation, Corrosion, Vol. 1, $3^{\text {rd }}$ ed., Butterworth Heinemann, London.

[38] Selwyn, L. (2004). Overview of archaeological iron: The corrosion problem, key factors affecting treatment, and gaps in current knowledge, in: Ashton, J., \& Hallam, D., (ed.) Metal 2004:
Proc. of interim meeting of the ICOM-CC Metal WG, National Museum of Canberra, Australia, pp. 294-306.

[39] Scott, D. \& Eggert, G. (2009). Iron and steel in art: Corrosion, colorants, conservation, Archetype, London.

[40] Patel, A. (2014). Conservation of Archaeological metal artifacts- emphasizing on copper/bronze, J. of Multidisciplinary Studies in Archaeology, Vol. 2, pp. 347-358.

[41] https://permalac.com/ (6-08-2020)

[42] Wolfe, J., Grayburn, R., Khanjian, H., et al. (2017). Deconstructing incralac: A formulation study of acrylic coatings for the protection of outdoor bronze sculpture, in: Bridgland, J. (ed.) Proc. of the ICOM-CC $18^{\text {th }}$ Triennial Conf., Copenhagen, Denmark, Int. Council of Museums, Paris, France, pp: 1-8.

[43] Rifai, M., Abdel Hamid, Z., Saleh, S. et al. (2015). Evaluation of new coatings for the protection of ornamental cast ironwork exposed in uncontrolled environment, IJCS, Vol. 6 (4), pp. 611624.

[44] Canadian Conservation Institute. (2007). Storage of Metals, CCI Notes, 9/2, Ottawa, Canada.

[45] Rimmer, M., Thickett, D., Watkinson, D. et al. (2013). Guidelines for the storage and display of archaeological metalwork. English Heritage, London. 